\title{
Revenue Discretionary Model Pengukuran Manajemen Laba: Berdasarkan Sektor Industri Manufaktur di Bursa Efek Indonesia
}

\author{
Nieken Herma Sari ${ }^{1}$; Nurmala Ahmar ${ }^{1}$ \\ ${ }_{1}^{1}$ STIE Perbanas Surabaya, Jl. Nginden Semolo 34-36, Surabaya 60118. \\ *Korespondensi penulis, email: nhermasari@yahoo.com
}

\begin{abstract}
ABSTRAK
Manajemen laba merupakan suatu tindakan manajemen untuk mengelola perolehan laba suatu perusahaan. Tujuan penelitian ini adalah untuk mngindikasikan adanya manajemen laba akrual dengan pengukuran discretionary revenue model. Penelitian ini mengadopsi pada penelitian yang dilakukan oleh Stubben (2010) dimana terdapat dua model pengukuran untuk mendeteksi adanya manajemen laba akrual. Model pengukuran tersebut adalah revenue discretionary model-yang terdiri dari revenue model dan conditional revenue model. Obyek penelitian ini yaitu perusahaan manufaktur yang terdaftar di Bursa Efek Indonesia. Teknik analisis data yang dilakukan adalah deskriptif statistik dengan mengetahui nilai residual pada masing-masing sektor industri. Hasil penelitian ini membuktikan bahwa dengan menggunakan revenue model mampu mengindikasikan 8 sektor industri dari jumlah keseluruhan 13 sektor industri pada perusahaan manufaktur yang terindikasi manajemen laba akrual. Dan dengan menggunakan conditional revenue model mampu mengindikasikan 11 sektor industri dari jumlah keseluruhan 18 sektor industri yang terindikasi manajemen laba akrual.
\end{abstract}

Kata kunci: Manajemen laba akrual, model pendapatan diskresioner.

\begin{abstract}
Earnings management is a management action to manage the profitability of a company. The purpose of this study is to indicate the accrual earning management using revenue discretionary model. This study adopts the research conducted by Stubben (2010) where there are two measurement models to detect the presence of accrual earnings management. The measurement model is the discretionary revenue model consists of conditional revenue model and revenue model. Object of this research is the companies listed in Indonesia Stock Exchange. The technique of data analysis is descriptive statistics to determine the residual value in each industry sector. These results prove that the revenue model is able to indicate the industrial sector 8 of the total 13 industries in the manufacturing companies indicated accrual earnings management. Conditional revenue model is able to indicate the industrial sector 11 of the total 18 sectors industry that overall indicated accrual earnings management.
\end{abstract}

Keywords: Accrual earnings management, revenue discretionary model.

\section{PENDAHULUAN}

Peningkatan pertumbuhan ekonomi di suatu negara di dukung dengan berkembangnya dunia bisnis. Setiap perusahaan membutuhkan tambahan dana dari pihak luar perusahaan guna kelangsungan hidup perusahaan tersebut. Oleh karena itu muncullah persaingan yang ketat antar perusahaan untuk tetap bertahan dan mampu bersaing serta dapat menarik investor yang bersedia memberikan dana. Dalam hal itu perusahaan diwajibkan menunjukkan kinerja yang baik dan sehat dengan memberikan informasi yang terdapat pada laporan keuangan perusahaan. Selain itu juga menghindari cara-cara menciptakan keuntungan sesaat dan lebih mengutamakan kelangsungan hidup perusahaan serta kepentingan para pemangku kepentingan. 
Gambaran mengenai kinerja perusahaan selama satu periode tertuang pada laporan keuangan. Para pengguna laporan keuangan selalu menitik beratkan pada tingkat laba perusahaan karena dapat menunjukkan prestasi manajemen dalam mengelola perusahaan serta sebagai indikator dalam pengukuran kinerja manajemen. Apabila tingkat laba yang diinginkan tidak dapat tercapai maka terdapat kemungkinan adanya tindakan manajemen laba. Hal itu dibuktikan dengan adanya beberapa skandal pelaporan akuntansi yang telah diketahui, antara lain skandal manajemen yang dilakukan oleh beberapa perusahaan besar seperti Xerox Corporation yang memanipulasi pendapatan perusahaan sebesar $6 \mathrm{M}$ USD.

Manajemen laba yang dilakukan oleh manajer tersebut timbul karena keinginan untuk meningkatkan kinerja perusahaan dengan laba besar serta adanya masalah keagenan yaitu konflik kepentingan antara pemilik/pemegang saham (principal) dengan pengelola/manajemen (agent) akibat tidak bertemunya utilitas maksimal di antara mereka. Manajemen laba dibagi menjadi dua kategori yaitu manajamen laba akrual dan manajemen laba nyata. Manajemen laba akrual dapat dilakukan melalui adanya kebijakan akrual yang ditetapkan pada Pernyataan Standar Akuntansi Keuangan No. 1 (Revisi 2009) paragraf 19, dimana dalam penyusunan laporan keuangan kecuali laporan arus kas didasarkan pada dasar akrual. Selain itu terdapat beberapa perubahan PSAK yang berdampak pada kebijakan akrual yang semakin terbatas, salah satunya mengenai pelaporan laba rugi komprehensif yang diterapkan mulai 1 Januari 2012. Perubahan tersebut berpengaruh terhadap pemilihan tahun penelitian karena laporan laba rugi merupakan sumber data dalam penelitian ini.

Laba merupakan komponen yang berasal dari selisih antara pendapatan dengan beban atau biaya. Oleh sebab itu pendapatan dan beban dapat dijadikan sebagai sasaran manajemen untuk mengelola laba. Berbagai macam model pendeteksian manajemen laba dapat digunakan untuk mengukur manajamen laba dalam sebuah perusahaan. Jones model merupakan model pendeteksi manajemen laba pertama yang diperkenalkan oleh Jones (1991) yang kemudian dikembangkan oleh Dechow et al. (1995) yang dikenal dengan modified Jones model.

Menurut Stubben (2010), terdapat beberapa kelemahan dari model modified Jones model yang diungkap seperti estimasi cross-sectional yang secara tidak langsung mengasumsikan bahwa perusahaan dalam industri yang sama menghasilkan proses akrual yang sama. Selain itu, model akrual juga tidak menyediakan informasi untuk komponen mengelola laba perusahaan dimana model akrual tidak membedakan peningkatan diskresioner pada laba melalui pendapatan atau komponen beban. Melihat kelemahan dari penelitian mengenai manajemen laba, Stubben (2010) mengembangkan model yang menggunakan komponen utama pendapatan yaitu piutang untuk memprediksi manajemen laba. Penelitian tersebut memberikan bukti bahwa model revenue biasnya lebih rendah, lebih spesifik, dan lebih kuat daripada model akrual. Penggunaan revenue model dalam mendeteksi manajemen laba juga dapat diterapkan pada perusahaan di Indonesia, namun belum banyak penelitian yang menggunakan model ini karena merupakan model baru yang dapat digunakan dalam mendeteksi manajemen laba. Perusahaan yang memiliki arus kas negatif cenderung melebih-lebihkan pendapatannya (Callen et al. 2008). Hal tersebut dilakukan dengan melakukan pengendalian terhadap kebijakan kredit yang dapat menyebabkan arus kas menjadi positif. Oleh karenanya, auditor menjadikan hal tersebut sebagai pelanggaran terhadap ketentuan standar akuntansi yang berlaku umum.

Perhitungan revenue discretionary model dalam mengukur manajemen laba yang akan diteliti secara lebih detil dapat dilihat pada gambar kerangka pemikiran seperti Gambar 1.

\begin{tabular}{|c|c|c|c|c|c|c|c|}
\hline $\begin{array}{c}\text { Food } \\
\text { and } \\
\text { Beverage }\end{array}$ & $\begin{array}{c}\text { Tobacco } \\
\text { Manufactu- } \\
\text { rers }\end{array}$ & \multicolumn{2}{|c|}{$\begin{array}{c}\text { Textile } \\
\text { Mill } \\
\text { Products }\end{array}$} & $\begin{array}{l}\text { Apparel and } \\
\text { Other } \\
\text { Textile } \\
\text { Products }\end{array}$ & \multicolumn{2}{|c|}{$\begin{array}{c}\text { Lumber } \\
\text { and Wood } \\
\text { Products }\end{array}$} & $\begin{array}{l}\text { Paper } \\
\text { and } \\
\text { Allied } \\
\text { Products }\end{array}$ \\
\hline $\begin{array}{l}\text { Automotive } \\
\text { and Allied } \\
\text { Products }\end{array}$ & \multirow[t]{2}{*}{$\begin{array}{c}\text { MANAJEMEN } \\
\text { LABA } \\
\text { AKRUAL }\end{array}$} & \multirow{2}{*}{\multicolumn{2}{|c|}{$\begin{array}{l}\text { REVENUE } \\
\text { MODEL } \\
\text { (STUBBEN) }\end{array}$}} & \multicolumn{2}{|c|}{$\Delta \mathrm{AR}_{\mathrm{it}}$} & \multirow{3}{*}{ e } & $\begin{array}{c}\text { Chemic } \\
\text {-al and } \\
\text { Allied }\end{array}$ \\
\hline $\begin{array}{l}\text { Photog- } \\
\text { raphic } \\
\text { Equipment }\end{array}$ & & & & & & & Adhe-sive \\
\hline Cement & \multicolumn{5}{|c|}{$\Delta \mathrm{AR}_{\mathrm{it}}=\alpha+\beta_{1} \Delta \mathrm{R} 1_{-} 3_{\mathrm{it}}+\beta_{2} \Delta \mathrm{R} \mathbf{4}_{\mathrm{it}}$} & & $\begin{array}{l}\text { Plastics } \\
\text { and Glass } \\
\text { Produkts }\end{array}$ \\
\hline $\begin{array}{l}\text { Pharma } \\
\text { ceuticals }\end{array}$ & $\begin{array}{l}\text { Electronic } \\
\text { and Office } \\
\text { Equipment }\end{array}$ & $\begin{array}{l}\text { Stone, } \\
\text { Clay, } \\
\text { Glass and } \\
\text { Concrete } \\
\text { Products }\end{array}$ & $\begin{array}{l}\text { Consu } \\
\text {-mer } \\
\text { Goods }\end{array}$ & Cables & & $\begin{array}{l}\text { ricated } \\
\text { Ietal } \\
\text { ducts }\end{array}$ & $\begin{array}{c}\text { Metal } \\
\text { and } \\
\text { Allied } \\
\text { Products }\end{array}$ \\
\hline
\end{tabular}

Gambar 1. Kerangka Penelitian Revenue Model

\begin{tabular}{|c|c|c|c|c|c|c|c|c|}
\hline $\begin{array}{l}\text { Food and } \\
\text { Beverages }\end{array}$ & \multirow{2}{*}{\multicolumn{2}{|c|}{$\begin{array}{c}\begin{array}{c}\text { Tobacco } \\
\text { Manufactu- } \\
\text { rers }\end{array} \\
\text { MANAJEMEN } \\
\text { LABA } \\
\text { AKRUAL }\end{array}$}} & \multicolumn{2}{|c|}{$\begin{array}{l}\text { Textile } \\
\text { Mill } \\
\text { Products }\end{array}$} & $\begin{array}{l}\text { Apparel and } \\
\text { Other } \\
\text { Textile } \\
\text { Products }\end{array}$ & \multicolumn{2}{|c|}{$\begin{array}{l}\text { Lumber } \\
\text { and Wood } \\
\text { Products }\end{array}$} & \multirow{2}{*}{$\begin{array}{l}\text { Paper } \\
\text { and } \\
\text { Allied } \\
\text { Produc } \\
\begin{array}{l}\text { Chemic } \\
\text { al and } \\
\text { Allied }\end{array}\end{array}$} \\
\hline $\begin{array}{l}\text { Automotive } \\
\text { and Allied } \\
\text { Products }\end{array}$ & & & & $\begin{array}{l}\text { CONDITI } \\
\text { ONAL } \\
\text { REVEN- } \\
\text { UE }\end{array}$ & \multicolumn{2}{|c|}{$\Delta \mathrm{AR}_{\mathrm{it}}$} & \multirow{3}{*}{ e } & \\
\hline $\begin{array}{c}\text { Photog- } \\
\text { raphic } \\
\text { Equipment }\end{array}$ & & & & $\begin{array}{l}\text { (STUB- } \\
\text { BEN) }\end{array}$ & $-c$ & $M_{i t}$ & & $\begin{array}{c}\text { Adhe- } \\
\text { sive }\end{array}$ \\
\hline Cement & \multicolumn{6}{|c|}{ 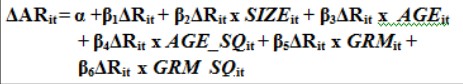 } & & $\begin{array}{c}\text { Plastics } \\
\text { and Glass } \\
\text { Produkts }\end{array}$ \\
\hline $\begin{array}{l}\text { Pharmace } \\
\text { uticals }\end{array}$ & $\begin{array}{c}\text { Consu- } \\
\text { mer } \\
\text { Goods }\end{array}$ & \multicolumn{2}{|c|}{ Cables } & $\begin{array}{l}\text { Electronic } \\
\text { and Office } \\
\text { Equipment }\end{array}$ & $\begin{array}{c}\text { Stone, Clay, } \\
\text { Glass and } \\
\text { Concrete } \\
\text { Products }\end{array}$ & \multicolumn{2}{|c|}{$\begin{array}{l}\text { Fabricated } \\
\text { Metal } \\
\text { Products }\end{array}$} & $\begin{array}{c}\text { Metal and } \\
\text { Allied } \\
\text { Products }\end{array}$ \\
\hline
\end{tabular}

Gambar 2. Kerangka Penelitian Conditional Revenue Model 


\section{Agency Theory}

Agency theory merupakan teori yang dapat dijadikan landasan untuk penelitian ini, dengan adanya pemisahan fungsi antara pemilik organisasi dan pelaku organisasi. Jika agen dan principal berupaya memaksimalkan utilitasnya masingmasing, serta memiliki keinginan dan motivasi yang berbeda, maka ada alasan untuk percaya bahwa agen (manajemen) tidak selalu bertindak sesuai keinginan prinsipal (Jensen \& Meckling 1976). Konflik keagenan dapat mengakibatkan adanya sifat manajemen melaporkan laba secara oportunis untuk memaksimumkan kepentingan pribadinya. Jika hal ini terjadi akan mengakibatkan adanya manajemen laba.

\section{Manajemen Laba}

Manajemen laba dilakukan dengan mempermainkan komponen-komponen akrual dalam laporan keuangan, sebab pada komponen akrual dapat dilakukan permainan angka melalui metode akuntansi yang digunakan sesuai dengan keinginan orang yang melakukan pencatatan dan penyusunan laporan keuangan. Komponan akrual merupakan komponen yang tidak memerlukan bukti kas secara fisik sehingga mempermainkan besar kecilnya komponen akrual tidak harus disertai dengan kas yang diterima atau dikeluarkan perusahaan (Sulistyanto 2008).

\section{Pola Manajemen Laba}

Menurut Scott (2007) terdapat empat pola manajemen laba yaitu:

a. Taking a bath

Taking a bath adalah pola manajemen laba yang dilakukan dengan cara menjadikan laba perusahaan pada periode berjalan menjadi sangat ekstrim rendah (bahkan rugi) atau sangat ekstrim tinggi dibandingkan dengan laba pada periode sebelumnya atau sesudahnya.

b. Income minimization

Income minimization adalah pola manajemen laba yang dilakukan dengan cara menjadikan laba pada laporan keuangan periode berjalan lebih rendah daripada laba sesungguhnya.

c. Income maximization

Maksimisasi laba (income maximization) adalah pola manajemen laba yang dilakukan dengan cara menjadikan laba pada laporan keuangan periode berjalan lebih tinggi daripada laba sesungguhnya.

d. Income Smoothing

Income smoothing atau perataan laba merupakan salah satu bentuk manajemen laba yang dilakukan dengan cara membuat laba akuntansi relative konsisten (rata atau smooth) dari periode ke periode.

\section{Revenue Discretionary Model}

Revenue Discretionary Model diperkenalkan oleh Stubben (2010) atas dasar ketidakpuasan terhadap model akrual yang umum digunakan saat ini. Terdapat dua formula dalam revenue discretionary model yang digunakan sebagai pengukuran manajemen laba. Pertama adalah revenue model, model ini menitikberatkan pada pendapatan yang memiliki hubungan secara langsung dengan piutang. Kedua yaitu conditional revenue model, model ini dikembangkan kembali dengan adanya penambahan ukuran perusahaan (size), umur perusahaan (age), dan margin kotor (GRM) yang diduga dapat digunakan dalam mendeteksi manajemen laba akrual mengenai pemberian kredit yang berhubungan dengan piutang. Ukuran perusahaan (firm size) merupakan proksi dari kekuatan finasial. Umur perusahaan merupakan proksi untuk tahap perusahaan dalamsiklus bisnis. Sebagai proksi dari kinerja operasional dari perbandingan perusahaan dengan perusahaan kompetitor, digunakan gross margin.

\section{METODE PENELITIAN}

\section{Rancangan Penelitian}

Penelitian ini merupakan penelitian kualitatif deskriptif yaitu metode penelitian dengan cara mendeskripsikan teknik perhitungan manajamen laba akrual dengan pendekatan revenue discretionnary model. Sumber data pada penelitian ini merupakan sumber data sekunder.Data yang diperoleh dari laporan keuangan triwulanan dan tahunan dari perusahaan manufaktur yang terdaftar di Bursa Efek Indonesia.Objek dalam penelitian ini adalah perusahaan manufaktur yang terdaftar di Bursa Efek Indonesia.Pengujian data dilakukan menggunakan SPSS (Statistic Program for Social Science) 19.0 for windows dengan melakukan uji analisis statistik deskriptif.

\section{Batasan Penelitian}

Batasan penelitian ini mencakup topik pembahasan mengenai manajemen laba akrual saja dan juga hanya satu model pengukuran yang digunakan yaitu revenue discretionary model. Penelitian ini bertujuan untuk pembuktian penggunaan model revenue discretionary dalam mendeteksi manajemen laba sehingga tidak mempertimbangkan perubahan-perubahan dalam 
konvergensi PSAK ke IFRS yang berpengaruh terhadap kebijakan akrual. Objek penelitian ini pun terbatas yaitu pada perusahaan sektor manufaktur yang terdaftar di Bursa Efek Indonesia.

\section{Data dan Metode Pengumpulan Data}

Dalam penelitian ini, metode pengumpulan data yang digunakan yaitu dengan metode dokumentasi karena data berupa data sekunder. Metode dokumentasi ini dilakukan dengan mengumpulkan laporan keuangan yang dibutuhkan. Data sekunder ini berupa laporan keuangan triwulanan dan laporan keuangan tahunan perusahaan manufaktur di Bursa Efek Indonesia yang dipublikasikan pada periode 2010-2012 dalam satuan rupiah untuk penggunaan revenue model. Kemudian untuk penggunaan conditional revenue modelhanya data laporan keuangan tahunan yang dijadikan sumber data. Data sekunder adalah sumber data yang diperoleh secara tidak langsung melalui media perantara. Data tersebut diperoleh dari situs Bursa Efek Indonesia www.idx.co.id dan IDX Fact Bookdan Indonesian Capital Market Directory (ICMD).

\section{Teknik Analisis Data}

Analisis deskriptif dilakukan untuk melihat karakteristik data penelitian.Sebelum melakukan pengolahan data, peneliti harus melakukan tabulasi data yang diperlukan terlebih dahulu. Untuk mendapatkan deskripsi tentang manajemen laba akrual dengan menggunakan pendekatan revenue discretionary model (Stubben 2010), serta analisis berdasarkan sektor industri dilakukan dengan tahapan sebagai berikut:

1. Mengukur dan menghitung manajemen laba akrual dengan menggunakan pendekatan revenue discretionary model (Stubben 2010). Berikut ini adalah formula dari revenue discretionary model (Stubben 2010):

a. Revenue Model $\Delta \mathrm{AR}_{i t}=\mathrm{a}+\mathrm{B}_{1} \Delta \mathrm{R} 1_{-} 3_{i t}+\mathrm{B}_{2} \Delta \mathrm{R} 4_{i t}+\mathrm{e}$

b. Conditional Revenue Model

$\Delta \mathrm{AR}_{\mathrm{it}}=\alpha+B_{1} \Delta \mathrm{R}_{\mathrm{it}}+B_{2} \Delta \mathrm{R}_{\mathrm{it}} \mathrm{x} S I Z E_{\mathrm{it}}+B_{3} \Delta \mathrm{R}_{\mathrm{it}}$ $\mathrm{x} A G E_{\text {it }}+B_{4} \wedge \mathrm{R}_{\text {it }} \mathrm{x} A G E_{-} S Q_{\text {it }}+B_{5} \Delta \mathrm{R}_{\text {it }} \mathrm{x} G R M_{\text {it }}$ $+B_{6} \Delta R_{\text {it }} \mathrm{x} G R M_{-} S Q_{\text {it }}+\mathrm{e}$

Keterangan:

$\mathrm{AR}$ = piutang akhir tahun

R1_3 = pendapatan pada tiga kuartal pertama

R4 = pendapatan pada kuartal ke4

SIZE = natural log dari total aset akhir tahun

$A G E$ = umur perusahaan (tahun)

$G R M=$ margin kotor

SQ = kuadrat dari variabel

$\mathrm{e} \quad=$ error
Langkah-langkah perhitungan:

a. Mentabulasi data yang menjadi komponen data perhitungan manajemen laba akrual dengan revenue discretionary model (Stubben, 2010). Data tersebut mencakup:

1. Perubahan pendapatan $(\Delta R)$

2. Piutang pada tiga kuartal pertama (R1_3)

3. Piutang pada kuartal ke-4 (R4)

4. Ukuran perusahaan dari total aset (SIZE)

5. Umur perusahaan $(A G E)$

6. Margin kotor (GRM)

b. Setelah mentabulasi semua data yang dibutuhkan, selanjutnya menentukan besarnya perubahan pendapatan dengan formula pada masing-masing model.

c. Menentukan ukuran perusahaan (SIZE) yang diperoleh dari natural log total aset.

d. Menentukan umur perusahaan yang digunakan dalam penelitian yang diperoleh dari laporan keuangan.

e. Menentukan besarnya margin kotor (GRM) dengan formula:

\section{Laba Kotor \\ Penjualan}

f. Menghitung kuadrat dari umur perusahaan $(A G E)$ dan margin kotor (GRM)

g. Setelah semua komponen data diketahui, hitung besarnya residual. Besarnya residual menunjukkan besarnya manajemen laba akrual.

2. Melakukan pengelompokkan manajemen laba akrual berdasarkan sektor industri. Pengelompokkan berdasarkan perhitungan pada tahap pertama.

3. Mengkaji dan menganalisis manajemen laba akrual berdasarkan sektor industri.

4. Melakukan pengklasifikasian nilai manajemen laba akrual dengan batasan - 0,075 sampai dengan 0,075 yang dinyatakan tidak terindikasi manajemen laba akrual. Batasan tersebut disesuaikan dengan penelitian yang dilakukan oleh Roychowdurry (2006) karena dianggap mendekati angka 0 dan juga adanya kesamaan konsep perhitungan nilai manajemen laba dengan penelitian yang dilakukan Stubben (2010).

Membuat kesimpulan dari analisis yang dilakukan sebelumnya.

\section{HASIL PENELITIAN DAN PEMBAHASAN}

Analisis deskriptif merupakan analisis yang memberikan gambaran atau deskripsi suatu data yang dilihat dari nilai rata-rata (mean), standar 
deviasi, varian, maksimum, minimum, sum, range, kurtosis dan skewness (kemiringan distribusi). Pada sub bab analisis deskriptif ini akan dijelaskan lebih rinci tentang gambaran atau deskripsi data yang digunakan dalam penelitian ini secara keseluruhan baik berdasarkan tahun maupun berdasarkan sektor industry

\section{a. Revenue Discretionary}

Berdasarkan pada Tabel 1 dapat diketahui bahwa secara keseluruhan selama periode 20102012 nilai rata-rata manajemen laba akrual mengalami peningkatan dan penurunan. Terdapat 13 sektor industri yang dijadikan obyek penelitian dan 8 diantaranya terindikasi manajemen laba. Hal tersebut diketahui dari nilai rata-rata tertinggi yang dimiliki oleh sektor industri plastics and glass products yang berarti terindikasi manajemen laba akrual dan nilai rata-rata terendah dimiliki oleh stone, clay, glass, and concrete products yang juga terindikasi manajemen laba akrual.

Gambar 3 merupakan gambaran dari nilai rata-rata tertinggi berdasarkan pada Tabel 1 yang dimiliki oleh sektor indsutri plastics and glass products. Dalam sektor industri tersebut terdapat empat perusahaan yang memenuhi karakteristik obyek penelitian terdiri dari BRNA, LMPI, SIMA, YPAS.

Tabel 1. Perkembangan Manajemen Laba dengan Revenue Model

\begin{tabular}{rlrrrr}
\hline \multirow{2}{*}{ No. } & \multicolumn{1}{c}{ Sektor Industri } & \multirow{2}{*}{ Mean } & \multicolumn{3}{c}{ Tahun } \\
\cline { 4 - 6 } & & & 2010 & 2011 & 2012 \\
\hline 1 & Apparel and Other Textile & -0.1907 & -0.0538 & -0.0924 & -0.4259 \\
& Products & & & & \\
2 & Automotive and Allied & -0.0225 & -0.0233 & 0.1477 & -0.1920 \\
& Products & & & & \\
3 & Cement & -0.0804 & -0.2579 & -0.1932 & 0.2097 \\
4 & Chemical and Allied & 0.0088 & -0.1355 & 0.0701 & 0.0918 \\
5 & Electronic and Office & 0.0995 & 0.5477 & -0.1892 & -0.0602 \\
& Equipment & & & & \\
6 & Food and Beverages & 0.1099 & 0.5552 & -0.1341 & -0.0915 \\
7 & Metal and Allied Products & -0.0554 & -0.2632 & 0.0801 & 0.0168 \\
8 & Paper and Allied Products & 0.0442 & -0.0187 & -0.1536 & 0.3049 \\
9 & Pharmaceuticals & -0.2117 & -0.3616 & -0.1163 & -0.1572 \\
10 & Plastics and Glass & 0.3781 & 0.9671 & 0.0144 & 0.1523 \\
& Products & & & & \\
11 & Stone, Clay, Glass, & -0.3159 & 0.0858 & -0.4725 & -0.561 \\
& and Concrete Products & & & & \\
12 & Textile Mill Products & -0.0336 & -0.76 & 0.4100 & 0.2489 \\
13 & Tobacco Manufacturer & -0.0946 & -0.029 & -0.1013 & -0.1534 \\
\hline
\end{tabular}

\section{PLASTICS AND GLASS PRODUCTS}

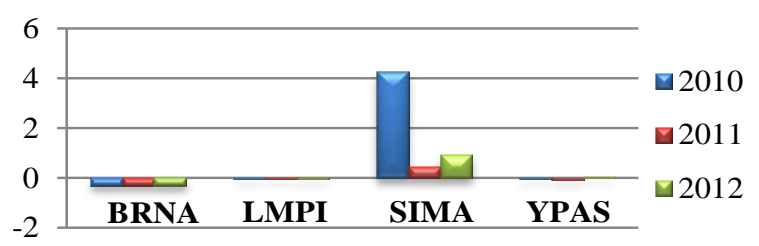

Gambar 3. Grafik Nilai MLA pada Sektor Industri Plastics and glass products
Berdasarkan pada Gambar 3 dapat dilihat bahwa terjadi fluktuasi manajemen laba pada masing-masing perusahaan selama tahun 20102012. Secara keseluruhan SIMA memiliki nilai residual paling tinggi bila dibandingkan dengan perusahaan lainnya. Nilai residual tertinggi dimiliki oleh SIMA pada tahun 2010 yang mengindikasikan terjadi manajemen laba karena nilai residualnya mencapai 4,2574, sedangkan nilai residual terendah dimiliki oleh BRNA pada tahun 2012 yang juga mengindikasikan terjadinya manajemen laba karena dikategorikan kurang dari 0,075 sehingga tidak mendekati angka nol.

Gambar 4 menunjukkan nilai rata-rata terendah berdasarkan pada Tabel 1 yang dimiliki oleh sektor industri stone, clay, glass, and concrete productsdapat dilihat bahwa terjadi perbedaan nilai residual diantara kedua perusahaan yang menjadi obyek penelitian. Nilai residual pada perusahaan IKAI lebih besar daripada perusahaan ARNA. Hal tersebut dapat mengindikasikan terjadi manajemen laba akrual pada perusahaan IKAI. Nilai residual tertinggi terjadi pada tahun 2012 yang dimiliki oleh IKAI, hal tersebut menandakan bahwa pada tahun tersebut perusahaan IKAI terindikasi manajemen laba karena nilai residual sebesar -0,9482. Sedangkan nilai residual terendah terjadi pada tahun 2010 yang dimiliki oleh ARNA sehingga dinyatakan tidak terindikasi manajemen laba karena nilai residual sebesar 0,0338 dikateghorikan lebih besar dai -0,075 maka mendekati nol.

Pada perusahaan ARNA nilai tertinggi terjadi pada tahun 2011 yaitu sebesar -0,2668 dan yang terendah terjadi pada tahun 2010 yaitu sebesar 0,338. Dari hasil tersebut dapat disimpulkan bahwa ARNA terindikasi manajemen laba selama tahun 2010-2012 karena nilai residual setiap tahunnya kurang dari dari -0,075. Kemudian pada perusahaan IKAI, nilai tertinggi terjadi pada tahun 2012 yaitu sebesar -0,9482 dan nilai residual terendah terjadi pada tahun 2010 yaitu sebesar 0,2054. Dari hasil tersebut dapat disimpulkan bahwa pada tahun 2010 dan 2012 IKAI terindikasi manajemen laba karena nilai residual tidak mendekati nol.

STONE, CLAY, GLASS, AND CONCRETE PRODUCTS

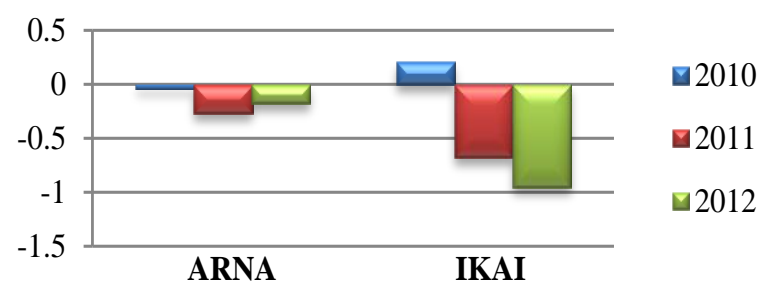

Gambar 4. Grafik Nilai MLA pada Sektor Industri Stone, Clay, Glass, and Concrete Products 
Tabel 2. Klasifikasi Nilai Manajemen Laba Akrual

\begin{tabular}{|c|c|c|c|c|c|}
\hline \multirow{2}{*}{ No. Klasifikasi } & \multirow{2}{*}{ Status } & \multicolumn{3}{|c|}{ Tahun } & \multirow{2}{*}{ Tota } \\
\hline & & 2010 & 2011 & 2012 & \\
\hline $1<-0,075$ & Terindikasi MLA & 25 & 27 & 30 & 82 \\
\hline $\begin{array}{cc}2-0,075 \text { s.d } \\
0,075\end{array}$ & Tidak Terindikasi MLA & 11 & 10 & & 28 \\
\hline \multirow[t]{2}{*}{$3>0,075$} & Terindikasi MLA & 16 & 15 & 15 & 46 \\
\hline & Total & 52 & 52 & 52 & 156 \\
\hline
\end{tabular}

Berdasarkan pada Tabel 2 dapat di lihat bahwa jumlah perusahaan yang terindikasi manajemen laba akrual pada tahun 2010 sebanyak 41 perusahaan dari total 52 perusahaan. Kemudian untuk tahun 2011 yang terindikasi manajemen laba akrual sebanyak 42 perusahaan dan untuk tahun 2012 sebanyak 45 perusahaan. Persentase terindikasinya manajemen laba akrual selama tahun 2010-2012 sebesar 82,05\%. Sedangkan pada tahun 2010 yang tidak terindikasi manajemen laba sebanyak 11 perusahaan. Kemudian pada tahun 2011 sebanyak 10 perusahaan dan tahun 2012 sebanyak 7 perusahaan dari total keseluruhan 52 perusahaan. Persentase perusahaan yang tidak terindikasi manajemen laba selama tahun 2010-2012 sebesar 17,95\%. Persentase perusahaan yang terindikasi manajemen laba lebih besar dari persentase perusahaan yang tidak terindikasi manajemen laba. Sehingga dapat disimpulkan bahwa dengan menggunakan revenue model sebagian besar perusahaan manufaktur terindikasi manajemen laba.

\section{b. Conditional Revenue Model}

Berdasarkan pada Tabel 3 dapat diketahui bahwa besarnya nilai rata-rata manajemen laba pada setiap sektor industri dan masing-masing tahun. Secara keseluruhan nilai rata-rata residual tertinggi dimiliki oleh sektor food and beverages yaitu sebesar 0,24138 nilai tersebut mengindikasikan adanya manajemen laba karena lebih besar dari 0,075 . Sedangkan nilai rata-rata residual terendah dimiliki oleh sektor paper and allied products yaitu sebesar -0,5402, hal itu menandakan bahwa tidak terindikasi manajemen laba. Sehingga apabila diamati dari rata-rata nilai residual, sektor industri tersebut dinyatakan terindikasi manajemen laba.

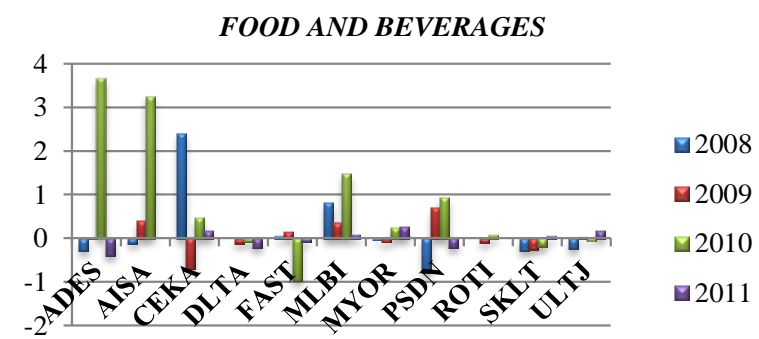

Gambar 5. Nilai MLA Pada Sektor Industri Food and Beverages

Berdasarkan pada Gambar 5 dapat diketahui bahwa nilai residual manajemen laba di setiap perusahaan berbeda-beda pada masing-masing tahunnya. Secara keseluruhan hampir semua perusahaan terindikasi adanya manajemen laba. Pada perusahaan ADES nilai residual tertinggi terjadi pada tahun 2010 yang mengindikasikan adanya manajemen laba dan nilai residual terendah terjadi pada tahun 2009 yang mengindikasikan tidak terjadi manajemen laba. Pada perusahaan AISA nilai tertinggi terjadi pada tahun 2010 mengindikasikan adanya manajemen laba dan nilai terendah pada tahun 2011 yang juga

Tabel 3. Perkembangan Manajemen Laba Akrual dengan Conditional Revenue Model

\begin{tabular}{|c|c|c|c|c|c|c|c|}
\hline \multirow{2}{*}{ No } & \multirow{2}{*}{ Sektor Industri } & \multirow{2}{*}{ Mean } & \multicolumn{4}{|c|}{ Tahun } & \multirow{2}{*}{$\mathbf{N}$} \\
\hline & & & 2008 & 2009 & 2010 & 2011 & \\
\hline 1 & Adhesive & 0.0595 & 0.5346 & -0.545 & 0.3006 & -0.0521 & 12 \\
\hline 2 & Apparel and Other Textile Products & -0.1057 & -0.2697 & -0.1339 & -0.1183 & 0.0697 & 24 \\
\hline 3 & Automotive and Allied Products & -0.0402 & -0.0341 & -0.3866 & 0.0721 & 0.1876 & 28 \\
\hline 4 & Cables & 0.1859 & -0.1851 & -0.5082 & 0.9591 & 0.4782 & 16 \\
\hline 5 & Cement & -0.1101 & -0.0765 & -0.0187 & 0.0170 & -0.0319 & 12 \\
\hline 6 & Chemical and Allied & 0.0149 & -0.5429 & 0.5816 & 0.3479 & -0.3267 & 12 \\
\hline 7 & Consumer Goods & 0.51 & 0.7015 & 0.5283 & 0.2150 & 0.5952 & 4 \\
\hline 8 & Electronic and Office Equipment & 0.0272 & 0.1312 & -0.22 & 0.4232 & -0.2254 & 8 \\
\hline 9 & Febricated Metal Products & -0.0979 & 0.0679 & -0.3486 & -0.095 & -0.0160 & 8 \\
\hline 10 & Food and Beverages & 0.2413 & 0.1385 & 0.0381 & 0.8036 & -0.0404 & 44 \\
\hline 11 & Lumber and Wood Products & -0.279 & -0.4235 & -0.0569 & -0.329 & -0.3064 & 8 \\
\hline 12 & Metal and Allied Products & -0.115 & 0.0188 & -0.4705 & -0.082 & 0.0738 & 28 \\
\hline 13 & Paper and Allied Products & -0.5402 & -0.3697 & -0.2634 & -1.8467 & 0.3189 & 20 \\
\hline 14 & Phamaceuticals & 0.0298 & -0.0297 & 0.3966 & -0.2283 & -0.0191 & 20 \\
\hline 15 & Plastics and Glass Products & 0.1589 & 0.2603 & 0.1852 & 0.3669 & -0.1769 & 28 \\
\hline 16 & Stone, Clay, Glass and Concrete Products & 0.0608 & 0.1524 & 0.0271 & 0.3847 & -0.3208 & 12 \\
\hline 17 & Textile Mill Products & 0.0681 & -0.1447 & -0.4287 & 0.3701 & 0.4757 & 16 \\
\hline 18 & Tobacco Manufacturers & -0.2366 & -0.3892 & -0.339 & -0.252 & 0.0337 & 8 \\
\hline
\end{tabular}


tidak mengindikasikan adanya manajemen laba. Kemudian pada perusahaan CEKA nilai tertinggi terjadi pada tahun 2008 yang mengindikasikan adanya manajemen laba. Pada tahun 2009 CEKA juga mengalami hal yang sama yaitu terindikasi manajemen laba karena nilai residualnya mencapai -0,6929. Sedangkan nilai terendah terjadi pada tahun 2011 sehingga juga terindikasi adanya manajemen laba. Selanjutnya untuk perusahaan FAST nilai residual tertinggi terjadi pada tahun 2010 dan nilai residual terendah terjadi pada tahun 2011. Pada perusahaan MLBI nilai residual yang melebihi dari ketetapan terjadi pada tahun 2008 dan 2010 sehingga pada tahun tersebut terindikasi manajemen laba. Pada perusahaan PSDN nilai residual yang mengindikasikan adanya manajemen laba terjadi selama tahun 20082010.

Berdasarkan pada Gambar 6 dapat diketahui bahwa terjadi fluktasi manajemen laba pada masing-masing perusahaan yang tergabung dalam sektor industri paper and allied product. Grafik tersebut menggambarkan perkembangan manajemen laba yang dimulai pada tahun 2008 sampai 2011.Secara keseluruhan nilai residual tertinggi dimiliki oleh INKP pada tahun 2010 yang mengindikasikan manajemen laba karena nilai residualnya mencapai $-7,675$. Sedangkan nilai residual terendah dimiliki oleh SPMA pada tahun 2008 yang tidak mengindikasikan terjadi manjemen laba karena nilai residualnya sangat mendekati nol. Dalam grafik tersebut juga dapat dilihat perusahaan yang terindikasi manajemen laba. Pada sektor paper and allied products terdapat tiga perusahaan yang terindikasi manajemen laba yaitu FASW, INRU dan SAIP. Sedangkan pada perusahaan lain tidak terindikasi manajemen laba akrual. Dari penyataan tersebut dapat ditarik kesimpulan bahwa dari kelima perusahaan yang dijadikan obyek penelitian terdapat tiga perusahaan yang terindikasi manajemen laba akrual.

PAPER AND ALLIED PRODUCTS

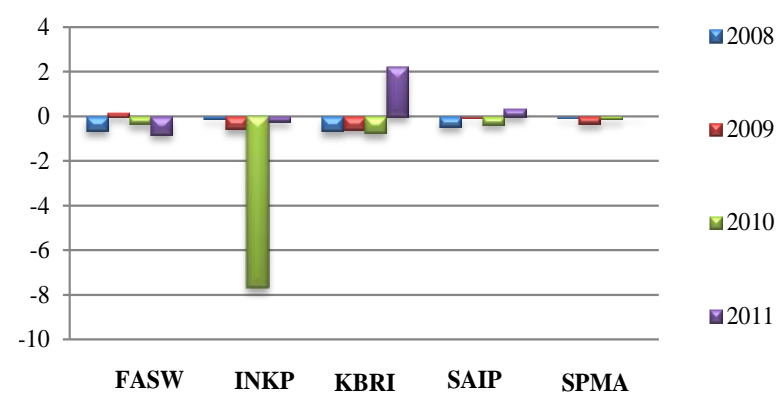

Gambar 6. Nilai MLA Pada Sektor Industri Paper and Allied Products
Tabel 4. Klasifikasi Nilai Manjemen Laba Akrual

\begin{tabular}{|c|c|c|c|c|c|c|c|}
\hline $\mathrm{No}$ & \multirow{2}{*}{$\begin{array}{c}\text { Klasifi- } \\
\text { kasi }\end{array}$} & \multirow{2}{*}{ Status } & \multicolumn{4}{|c|}{ Tahun } & \multirow{2}{*}{ Tot } \\
\hline No. & & & 2008 & 2009 & 2010 & $\overline{011}$ & \\
\hline \multirow[t]{2}{*}{1} & $<-0,075$ & Terindik & 43 & 50 & 38 & 33 & 164 \\
\hline & $-0,075 \mathrm{~s} . \mathrm{c}$ & Tidak T & & & & & \\
\hline 2 & 0,075 & MLA & 15 & 13 & 9 & 12 & 49 \\
\hline & $>0,075$ & Terindikasi MLA & 19 & 14 & 30 & 32 & 95 \\
\hline & & Total & 77 & 77 & 77 & 77 & 308 \\
\hline
\end{tabular}

Tabel 5. Komponen Perhitungan Revenue Model

\begin{tabular}{lccc}
\hline \multicolumn{1}{c}{ Komponen } & \multicolumn{3}{c}{ Tahun } \\
\cline { 2 - 4 } & 2010 & 2011 & 2012 \\
\hline Piutang Usaha & 550.771 & 714.893 & 864.084 \\
Pedapatan Kuartal ke-3 & 5.375 .225 & 6.526 .858 & 7.637 .923 \\
PendapatanKuartal ke-4 & 7.307 .155 & 8.899 .294 & 10.298 .658 \\
Perubahan Piutang Usaha & 0.3772 & 0.2102 & 0.2329 \\
Perubahan Pendapatan & 0.2421 & 0.2706 & 0.0775 \\
Kuartal ke-3 & & & \\
Perubahan Pendapatan & 0.3276 & 0.1968 & 0.0850 \\
Kuartal ke-4 & & & \\
\hline
\end{tabular}

Berdasarkan pada Tabel 4 dapat dilihat bahwa jumlah perusahaan yang dijadikan obyek penelitian sebanyak 77 perusahaan.Tabel tersebut menunjukkan adanya perusahaan yang terindikasi manajemen laba pada tahun 2008 sebanyak 62 perusahaan dari total 77 perusahaan. Kemudian untuk tahun 2009 yang terindikasi manajemen laba sebanyak 65 perusahaan dan untuk tahun 2010 sebanyak 68 perusahaan. Daan untuk tahun 2011 sebanyak 64 perusahaan yang terindikasi manajamen laba akrual. Persentase terindikasinya manajemen laba selama tahun 2008-2011 sebesar 84,42\%. Sedangkan pada tahun 2008 yang tidak terindikasi manajemen laba sebanyak 15 perusahaan. Kemudian pada tahun 2009 sebanyak 12 perusahaan dan tahun 2010 sebanyak 9 perusahaan dan tahun 2011 sebanyak 12 perusahaan dari total keseluruhan 77 perusahaan. Persentase perusahaan yang tidak terindikasi manajemen laba selama tahun 2008-2011 sebesar 15,58\%. Persentase perusahaan yang terindikasi manajemen laba lebih besar dari persentase perusahaan yang tidak terindikasi manajemen laba. Sehingga dapat disimpulkan bahwa dengan menggunakan conditional revenue model sebagian besar perusahaan manufaktur yang terindikasi manajemen laba.

Model dari Stubben (2010) ini menggunakan piutang sebagai fungsi dari perubahan pendapatan. Piutang dianggap memiliki hubungan kuat dan hubungan langsung pada pendapatan. Hal ini juga berhubungan dengan kebijakan manajemen yang dapat menentukan dalam pemberian kredit. Ketika pendapatan mengalami kenaikan maka dapat disertai dengan kenaikan piutang. Piutang yang tidak normal, tinggi atau rendah, dianggap mengindikasikan adanya manajemen pendapatan. 
Teori tersebut terbukti dalam penelitian ini dimana peningkatan pendapatan juga mengakibatkan peningkatan pula pada piutang usaha. Pola manajemen laba yang dapat dilakukan pada model ini yaitu dengan cara menaikkan angka laba atau juga dengan menurunkan angka laba yang berhubungan langsung dengan perolehan pendapatan.

Komponen perhitungan conditional revenue model terdapat penambahan komponen selain pendapatan yaitu umur perusahaan, ukuran perusahaan dan gross profit margin. Stubben (2010) menilai bahwa umur perusahaan, ukuran perusahaan dan gross profit margin mampu menjelaskan piutang usaha pada akhir tahun.Penggunaan ukuran perusahaan dianggap mampu mewakili kekuatan finansial perusahaan tersebut. Kemudian untuk umur perusahaan merupakan tahapan perusahaan dalam siklus bisnis sehingga dapat mengetahui perkembangan setiap tahunnya. Apakah perusahaan dengan jangka waktu berdirinyap perusahaan yang sudah lama juga terbukti terindikasi manajemen laba akrual. Sedangkan gross profit margin dianggap suatu komponen yang mampu mewakili kinerja operasional perusahaan dan dapat diperbandingkan dengan pesaing lain. Berdasarkan Tabel diatas dapat dilihat bahwa nilai perkomponen menandakan adanya penurunan dan peningkatan disetiap tahunnya. Perubahan tersebut juga berpengaruh terhadap besarnya piutang usaha sebagai komponen utama sehingga apabila terjadi peningkatan maka piutang usaha juga akan bertambah. Sedangkan apabila terjadi penurunan maka piutang usaha juga akan mengalami penurunan.

Tabel 6. Komponen Perhitungan Conditional Revenue Model

\begin{tabular}{lrrrr}
\hline \multirow{2}{*}{ Komponen Perhitungan } & \multicolumn{4}{c}{ Tahun } \\
\cline { 2 - 6 } & 2008 & 2009 & 2010 & 2011 \\
\hline $\begin{array}{l}\text { Piutang Usaha (REC) } \\
\text { Pendapatan (REV) }\end{array}$ & 240,523 & 241,835 & 281,370 & 299,713 \\
Ukuran Perusahaan & $2,263,0202,033,8172,582,3162,913,415$ \\
(SIZE) & 5.902 & 5.879 & 5.916 & 5.952 \\
Umur Perusahaan (AGE) & 31.79 & 32.79 & 33.79 & 34.87 \\
GRM & 0.189204 & -0.0094 & 0.09942 & 0.22968 \\
$\begin{array}{l}\text { Perubahan Pendapatan } \\
\text { (DREV) }\end{array}$ & 0.5852 & -0.0295 & 0.33608 & 0.26218 \\
$\begin{array}{l}\text { Pedapatan dan Size } \\
\text { (DREVSIZE) }\end{array}$ & 3.4612 & -0.1227 & 2.31884 & 1.55259 \\
$\begin{array}{l}\text { Pendapatan dan Umur } \\
\text { (DREVAGE) }\end{array}$ & 14.633 & -1.0177 & 10.5833 & 8.49725 \\
$\begin{array}{l}\text { Pendapatan dan Umur } \\
\text { kuadrat (DREVAGE_SQ) }\end{array}$ & 20,248 & -855.84 & 17526.5 & 12291.3 \\
$\begin{array}{l}\text { Pendapatan dan GRM } \\
\text { (DREVGRM) }\end{array}$ & 0.1054 & 0.22877 & 0.16869 & 0.06527 \\
$\begin{array}{l}\text { Pendapatan dan GRM } \\
\text { kuadrat (DREVGRM_SQ) }\end{array}$ & 0.0337 & -1.3062 & -0.058 & 0.03371 \\
\hline
\end{tabular}

Hasil penelitian secara umum konsisten dengan beberapa hasil penelitian sebelumnya, dimana pendapatan dan kontra akunnya, yaitu piutang merupakan akun yang dapat dimanfaatkan untuk melakukan manajemen laba (Stubben 2010; Callen et al. 2008). Hasil penelitian ini sekaligus memberikan pembuktian atas hasil riset yang dilakukan oleh Gunny (2005), Kristina \& Siregar (2008), Oktorina dkk. (2008). Penelitian tersebut mengungkapkan bahwa pendapatan dan piutang merupakan bagian dalam pengukuran manajemen laba akrual, meskipun terjadi pergeseran perilaku manajer dalam melakukan manajemen laba, yaitu manajemen laba akrual menuju manajemen laba riil.

\section{KESIMPULAN DAN SARAN}

Berdasarkan pada hasil analisis dengan menggunakan revenue model sebanyak 8 sektor industri yang terindikasi manajemen laba akrual selama tahun 2010-2012. Kedelapan sektor industri tersebut terdiri dari apparel and other textile products, cement, electronic and office equipment, food and beverages, pharmaceuticals, plastic and glass products, stone, clay, glass and concrete products, dan tobacco manufacturers. Sedangkan lima sektor lainnya dinyatakan tidak terindikasi manajemen laba akrual dengan pendekatan RDM. Kelima sektor tersebut adalah automotive and allied products, chemical and allied, metal and allied products, paper and allied products, dan textile mill products.

Pada pengukuran conditional revenue model (CRM) terdapat 18 sektor industri yang dijadikan obyek penelitian. Dari 18 sektor tersebut yang terindikasi manajemen laba akrual sebanyak 11 sektor industri yang terindikasi manajemen laba akrual. Kesebelas sektor industri tersebut adalah apparel and other textile products, cables, cement, consumer goods, fabricated metal products, food and beverages, lumber and wood products, metal and allied products, paper and allied products, plastics and glass products dan tobacco manufacturers. Dari kesebelas sektor industri tersebut yang memiliki nilai rata-rata tertinggi adalah food and beverages dan nilai terendah dimiliki oleh paper and allied products. Sedangkan 7 perusahaan lainnya dinyatakan tidak terindikasi manajemen laba akrual dengan pendekaran CRM.

Klasifikasi nilai manajemen laba berdasarkan pada pengukuran revenue model membuktikan bahwa terdapat 41 perusahaan yang terindikasi manajemen laba pada tahun 2010. Kemudian untuk tahun 2011 yang terindikasi manajemen laba sebanyak 42 perusahaan dan untuk tahun 2012 sebanyak 45 perusahaan. 
Persentase terindikasinya manajemen laba selama tahun 2010-2012 sebesar 82,05\%. Sedangkan pada tahun 2010 yang tidak terindikasi manajemen laba sebanyak 11 perusahaan. Kemudian pada tahun 2011 sebanyak 10 perusahaan dan tahun 2012 sebanyak 7 perusahaan dari total keseluruhan 52 perusahaan. Persentase perusahaan yang tidak terindikasi manajemen laba selama tahun 2010-2012 sebesar 17,95\%. Berdasarkan hasil persentase dapat disimpulkan bahwa dengan menggunakan revenue model sebagian besar perusahaan manufaktur terindikasi manajemen laba.

Selanjutnya untuk klasifikasi nilai manajemen laba akrual dengan pengukuran conditional revenue model dapat membuktikan bahwa terdapat 62 perusahaan yang terindikasi manajemen laba pada tahun 2008. Kemudian untuk tahun 2009 yang terindikasi manajemen laba sebanyak 65 perusahaan dan untuk tahun 2010 sebanyak 68 perusahaan. Dan untuk tahun 2011 sebanyak 64 perusahaan yang terindikasi manajamen laba. Persentase terindikasinya manajemen laba selama tahun 2008-2011 sebesar 84,42\%. Sedangkan sisanya merupakan perusahaan yang tidak terindikasi manajemen laba selama tahun 2008-2011 dengan persentase sebesar 15,58\%. Berdasarkan hasil tersebut dapat disimpulkan bahwa dengan menggunakan conditional revenue model hampir seluruh perusahaan manufaktur pada masingmasing industri dinyatakan terindikasi manajemen laba.

Keterbatasan penelitian ini adalah peneliti tidak memperoleh data secara lengkap sehingga mengurangi jumlah obyek penelitian yang akan diteliti. Hal itu dikarenakan tidak banyak perusahaan yang mempublikasikan laporan keuangan triwulanan dan tahunan selama periode penelitian. Peneliti tidak menggunakan periode 2012 dalam penelitian dikarenakan adanya perubahan konvergensi IFRS yang mulai diberlakukan sehingga tidak dapat membandingkan bagaimana manajemen laba akrual pada perusahaan manufaktur ketika sebelum perubahan kebijakan dan setelah perubahan kebijakan. Dan Peneliti tidak membahas komponen komponen perubahan dalam konvergensi IFRS yang berdampak pada hasil penelitian.

Implikasi pada riset mendatang adalah pada penggunaan pendekatan CRM dan RM sebagai pengukur manajemen laba. Riset selanjutnya juga menambah jumlah obyek penelitian tidak hanya pada perusahaan manufaktur saja sehingga hasil penelitian semakin baik. Kemudian disarankan akan lebih baik jika peneliti selanjutnya mempertimbangkan adanya perubahan-perubahan kebijakan dalam IFRS yang juga berpengaruh terhadap manajemen laba akrual. Salah satu tujuan implementasi IFRS secara mandatory adalah mengurangi perilaku manajemen laba para manajer. Namun beberapa penelitian menunjukkan bahwa terdapat pergeseran perilaku manajemen laba, dari akrual menuju riil. Model Stubben dengan menggunakan akun piutang dan pendapatan dengan data tiga bulanan menjadi alternatif penting dalam melakukan manajemen laba secara akrual namun memiliki akurasi yang lebih baik.

\section{DAFTAR PUSTAKA}

Callen, J. L., Robb, S. W., \& Segal, D. (2008). Revenue manipulation and restatements by loss firms. Auditing: A Journal of Practice \& Theory, 27(2), 1-29.

Dechow, P. M., Sloan, R. G. \& Sweeney, A. P. (1995). Detecting Earnings Management. The Accounting Review, 70(2), 193-225.

Gunny, K. (2005). "What are the Consequences of Real Earnings Management?". Working Paper, University of Colorado, 1-46.

Jensen, M. C., \& Meckling, W. H. (1976). Theory of the Firm: Managerial behaviour, agency Cost and Ownership Structure. Journal of Financial Economics, 3(4), 305-360.

Jones, J. J. (1991). Earnings Management During Import Relief Investigations. Journal of Accounting Research, 29(2), 193-228.

Kristina, B. M. \& Siregar, B. (2008). Pengaruh Manajemen Laba Nyata Terhadap Kinerja. Jurnal Akuntansi dan Manajemen, 19(3), 185-196.

Oktorina, Megawati, \& Yanthi. (2008). Analisis Arus Kas Kegiatan Operasi dalam Mendeteksi Manipulasi Aktivitas Rill dan Dampak Terhadap Kinerja Pasar. Simposium Nasional Akuntansi XI, Pontianak .

Ikatan Akuntan Indonesia. (2009). Pernyataan Standar Akuntansi Keuangan No. 1 (Revisi 2009).

Scott, W. R. (2012). Financial Accounting Theory, $6^{\text {th }}$ Edition. Prentice Hall

Stubben, S. R. (2010). Discretionary Revenues as a Measure of Earnings Management. The Accounting Review, 85(2), 695-717.

Sulistyanto, S. (2008). Manajemen Laba: Teori dan Model Empiris. Jakarta: Grasindo. 